\title{
Analytical and Preparative Thin-Layer Chromatography of Porphyrin Methyl Esters
}

\author{
By M. Doss \\ From the Clinical Biocbemistry Laborartory, Hygiene Institute of the University, Marburg/Labn, B.R.D.
}

(Eingegangen am 9. Februar 1970)

Thin-layer chromatography methods on the preparative and analytical scale are presented for the separation of porphyrin methyl esters according to the number of ester groups in each porphyrin. Complete and sharp separations are obtained on silica gel glass plates or aluminium cards run in benzene-ethyl acetate-methanol solvent systems. Dicarboxylic porphyrin esters from proto-, deutero- and hematoporphyrin IX have also been separated. Modifications of the analytical methods are described for the rapid separation of porphyrins bearing eight to two methyl ester groups within $10 \mathrm{~min}$ on small chromatocards in chloroform-ethyl acetate solvent mixtures.

The porphyrins are determined quantitatively by spectrophotometric analysis of the eluted substances, or by fluorescence scanning of the bands of thin-layer chromatograms, using the Camag-Turner TLC-scanner. The fluorometric method is highly sensitive and permits a simultaneous relative measurement of all bands in the chromatogram. Examples of thin-layer chromatograms in combination with fluorescence scanning are presented, demonstrating the application of this ncw analytical method.

Es werden dünnschichtchromatographische Methoden zur Trennung von Porphyrinmethylestern nach Anzahl der Carboxylgruppen im Porphyrin für den präparativen und analytischen Bereich beschrieben. Vollständige und scharfe Trennungen werden auf KieselgelSchichten mit Lösungsmittelsystemen erzielt, dic aus Benzol-Essigsäureäthylester-Methanol bestehen. Proto-, Deutero- und Hämatoporphyrindimethylester werden ebenfalls voneinander getrennt. Die analytischen Trennverfahren wurden auch für Schnellmethoden auf kleinen Dünnschichtkarten modifiziert, die in Chloroform-Essigsäureäthylester-Lösungsmittelsystemen eine Trennung der Porphyrine von acht bis zwei Methylestergruppen innerhalb von 10 Min. gewährleisten.

Die Porphyrine werden quantitativ entweder durch spektrophotometrische Analyse der eluierten Substanzen oder durch Fluoreszenzregistrierung der Banden im Dünnschichtchromatogramm im Camag-Turner DC-Auswertegerät bestimmt. Die fluorometrische Methode ist sehr empfindlich und exlaubt die gleichzeitige relative Messung der einzelnen Porphyrine des gesamten Chromatogramms. Einige Beispiele der direkten fluorometrischen Messung von Chromatogrammen zeigen den Anwendungsbereich dieser neuen analytischen Methode.

In recent years thin-layer chromatography (TLC) has begun to play an essential part in the complex field of porphyrin research: in the studies both of porphyrin and heme synthesis in various biological systems, and of biochemical diagnosis and pathogenesis of porphyrias; for the isolation of relatively large amounts of pure substances from natural sources; and for the identification of the individual porphyrins in combination with spectrophotometry, fluorometry, formation of metal complexes, and fluorescence scanning measurement. The analysis of porphyrins in very low concentrations in urine, erythrocytes, bile, liver biopsy, gastric and duodenal juice has been made possible by means of silica gel TLC.

In 1958 Demore (1) was the first to carry out chromatograpic adsorption analysis of tetrapyrrole pigments as methyl esters on silicic acid thin-layers. Considerable progress has since been made, and during the last few years several workers have described methods for thinlayer separation of porphyrins, both as free acids and as methyl esters. These principles are reviewed elsewhere (2).

Based upon the work in the author's laboratory, this report describes preparative and analytical chromatographic separation of porphyrin carboxylic acid methyl esters on thin layers of silica gel.

Porphyrin esters are easily prepared for TLC using methanol-sulphuric acid mixtures either of isolated porphyrin acids, or of porphyrins from biological materials of various origins (3-10). The separation and analysis of the porphyrins as methyl esters has proved superior to the separation and analysis of the free porphyrin acids in several respects:

1. the rapid and quantitative extraction of the crude total porphyrin mixture

2. the high solubility of porphyrin methyl esters in a small volume of a single solvent, e. g., chloroform

3. the many possibilities for preparative and analytical separations on silica gel layers without preliminary purification. According to the respective number of methyl ester groups, the porphyrins appear as sharp spots or bands, allowing

4. rapid and clear separations on ready-made layers for diagnostic work

5. analytical thin-layer chromatography by means of quantitative fluorescence scanning

6. rapid elution of the esters from the adsorbent

7. various combinations with spectrophotometry, and calculations on the basis of extinction coefficients alone

8. the identification of porphyrins by the positions of the absorption maxima in chloroform, along with chromatographic data 
9. conversion into $\mathrm{Zn}$ or $\mathrm{Cu}$ chelates, which exhibit higher absorption in spectrophotometry compared to metal-free esters

10. the simultaneous separation and determination of hemin as a methyl ester.

In preparing porphyrins of biological origin, it is advisable to esterify the whole mixture first, and then to separate it into its individual components. We start with lyophilzed tissue or cells, or with dried talc layers to which porphyrins from fluids have been adsorbed. Methanol-sulphuric acid is added to this material, leading to the conversion of the free porphyrin carboxylic acids into methyl esters in the course of acidcatalyzed esterification. The porphyrin methyl esters show characteristic lipophilic properties, and, unlike the free carboxylic acids, differ from one another only slightly in their solubility. Thus all the porphyrins with 2 to 8 methyl ester groups in the molecule, corresponding to the biosynthetic sequence, can easily be extracted quantitatively from a methanol-sulphuric acid-water mixture, by use of chloroform. The methyl ester extract is separated by TLC on silica gel plates or cards as shown in chromatograms of Figures 1 to 3 . There is complete separation of the individual porphyrins, which are uniform' compounds as regards molecular weight.

\section{Experimental procedure}

\section{Porpbyrins and protobemin as reference substances}

Reference samples of porphyrin methyl esters were isolated according to our own method $(3,5,6)$ from urine of Porphyria cutanea tarda patients, and from cell suspensions (cells plus culture fluid) of Achromobacter metalcaligenes. The latter is capable of synthesizing all of the porphyrins occurring in the biosynthetic chain out of $\delta$-aminolevulinic acid (purchased from Fluka, Buchs, Switzerland) added to the culture. For this purpose we used a final concentration of $\delta$-aminolevulinic acid of between 0.1 and $0.5 \mathrm{~mm}$ in the culture. Protohemin IX dimethyl ester was prepared from hemin(chloride) purum (Fluka) by means of esterification, extraction, recrystallization and subsequent further purification in TLC (9).

\section{Materials and equipment for TLC}

For preparative purposes $20 \times 20 \mathrm{~cm}$ glass plates were cleaned thoroughly with methanol and coated thinly with a layer of Silica Gel H (Merck, Darmstadt, B. R. D.). This was done with the aid of a coating apparatus from Camag (Muttenz, Switzerland). The thickness of the layer can be varied according to need from 0.5 to $2.0 \mathrm{~mm}$.

For the isolation of microquantities of porphyrin and protohemin methyl esters and for subsequent analysis, pre-coated plates or cards with a layer thickness of $0.2-0.3 \mathrm{~mm}$ are preferable. In this laboratory the analytical work of TLC is carried out on silica gel aluminium cards, layer thickness $0.2 \mathrm{~mm}$ (Riedel-de Haën, Seelze, Hannover, B. R. D.), silica gel plates DSF-A, $0.2 \mathrm{~mm}$ (Camag), and Silica Gel $\mathrm{F}_{254}$ plates, $0.25 \mathrm{~mm}$ (Merck).

As a tank for chromatograms ranging in size from $95 \times 180$ to $200 \times 200 \mathrm{~mm}$, a developing chamber from Camag (25250) having a flat bottom and inner dimensions of $215 \times 215 \times 60 \mathrm{~mm}$ was used exclusively. Especially rapid separations are achieved in micro-tanks (Camag).

The porphyrin solutions were applied either with fine capillaries, such as can be drawn out of glass tubing, or with self-filling micro-pipettes (Camag).
Preparation of biological material for cljromatography of porphyrins as metbyl esters

Tissues and cells are dried, care being taken to shield them from light. We prefer to freeze-dry liver tissue, blood cells, microorganisms and cell cultures (cells alone as well as cells plus medium). In contrast, porphyrins in liquids such as urine, gastric or duodenal secretion, supernatants from microbial cultures or cell cultures are adsorbed on talc (talc: Merck (DAB 7) or Riedelde Haën (DAB 6)) after the liquid has been adjusted to $\mathrm{pH} 4-5$ with glacial acetic acid. According to the expected concentration of porphyrins, $0.2-0.8 \mathrm{~g}$ of talc are added for each $10 \mathrm{ml}$ of liquid. Adsorption is complete after one minute, aided by shaking of the suspension. The talc is either sedimented or removed by means of a porcelain suction filter. For the isolation of porphyrins from microbial culture (cells plus culture fluid), talc is added, which adsorbs the cells and the porphyrins in the medium. The preparation of porphyrins from a suspension of animal cells is achieved by the usual talc adsorption in the liquid phase, with simultaneous sedimentation both of the cells and the talc. After drying at $35^{\circ}$ or freeze-drying of the talc-adsorbed samples, the porphyrins are esterified with methanol-sulphuric acid as described below.

\section{Esterification of the porphyrins}

Porphyrins and protoheme are esterified with methanol-sulphuric acid ( $1-5$ vol. $-\%$ conc. sulphuric acid) by suspending the dried cell material or talc with substances adsorbed to it in methanolsulphuric acid. The reaction is complete for practical purposes within 10 hours at $18-21^{\circ}$. The amount both of adsorbed porphyrins and of talc used in relation to the volume of the esterification mixture plays an essential role in the rapidity and completeness of the reaction. Porphyrinogens are oxidized to porphyrins by treatment with methanol-sulphuric acid. The continuous increase of fluorescence after admixture of methanol-sulphuric acid until a constant intensity is reached indicates the oxidation of the hexahydro-porphyrins to porphyrins, as was observed in the analysis of bacterial cell-free systems (8). The methyl ester of hemin is also formed during esterification.

The following is a simple method for analytical amounts: 10 to $100 \mathrm{mg}$ of cells or tissues (dry weight) or $0.5 \mathrm{~g}$ talc, on which the porphyrins from, for example, $10 \mathrm{~m} l$ of urine are adsorbed, are suspended in about $4 \mathrm{ml}$ of methanol-sulphuric acid $(95+5$, $v+v$ ), which esterifies the porphyrins within 6 hours at room temperature, or in $30 \mathrm{~min}$. at $35^{\circ}$ (Fig. 4). Following the addition of a like volume of chloroform, the talc is again sedimented, and the supernatant filtered into an extraction vessel (5). The talc is stirred up an additional 1-3 times with about $2 \mathrm{~m} l$ of chloroform, so that the porphyrins may by completely eluted from the talc (checked under a UV-lamp at $366 \mathrm{~nm}$ for red fluorescence). The solution is drawn off into an extraction vessel, in which the porphyrin methyl esters are then shaken out against water. Extraction is repeated with $2 \mathrm{ml}$ of chloroform, in order to abtain a complete yield. The chloroform extract is washed to neutrality with $5 \mathrm{ml}$ of a $5 \%(\mathrm{w} / \mathrm{v})$ aqueous solution of sodium hydrogen carbonate. Before the solvent is evaporated, it is dried with a small amount of anhydrous sodium sulphate and filtered. No destruction of porphyrins, especially of protoporphyrin, was observed following the esterification procedures.

\section{Preparative chromatograpby}

The preparative isolation of milligram amounts of porphyrins as methyl esters is carried out on Silica Gel H layers, coated on $20 \times 20 \mathrm{~cm}$ glass plates. The separating capacity of a plate depends mainly upon the thickness of the coat. This can vary from 0.5 to $0.2 \mathrm{~mm}$, depending on tequirements. On the basis of our own experience, however, the quality of separation on the preparative scale is best in a layer of $0.8-1.2 \mathrm{~mm}$ thickness.

An example of thin-layer chromatographic isolation of porphyrins from the urine of a patient with chronic hepatic porphyria is given in Figure 1. The methyl ester extract of total porphyrins was prepared from urine in the following manner: The porphyrins from $1 l$ of urine the $\mathrm{pH}$ of which had been adjusted, to 4 with 


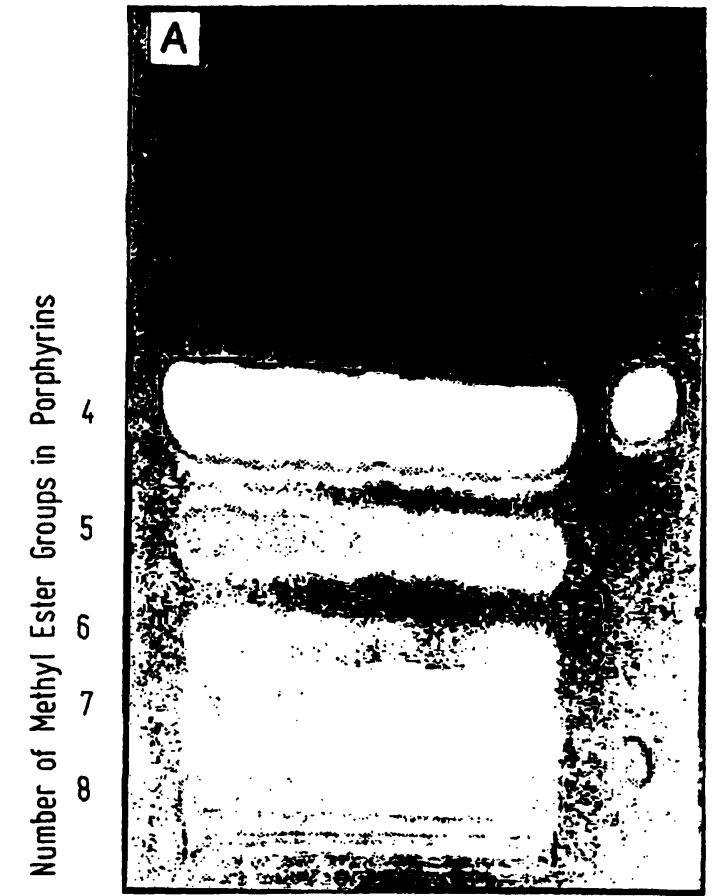

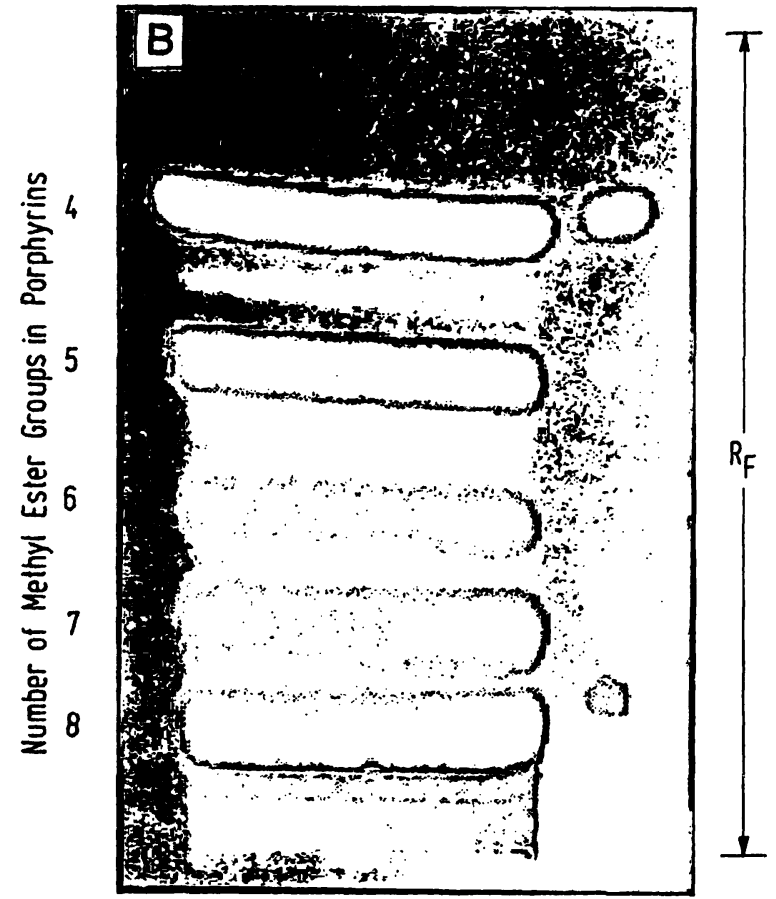

Fig. 1

Preparative separation of porphyrins on Silica Gel $\mathrm{H}$ thin-layer plates $(20 \times 20 \mathrm{~cm})$ having a layer thickness of $1 \mathrm{~mm}$. Applied in a band $10 \mathrm{~cm}$ wide, about $1 \mathrm{mg}$ of a mixture of porphyrin methyl esters was separated by running the plate twice (A and $B$ ) in the solvent system benzene-ethyl acetate-methanol $(85+13+2, v+v)$. The time for one development was about 40 min. at $21^{\circ}$. The uro- and coproporphyrin methyl ester reference compounds were run on the right side of the plate. Data for photographing the chromatograms under two ultraviolet lamps ( 366 nm): film Ilford FP4, lens Jena $T(1: 2.8$, focal length $=50 \mathrm{~mm}), B+W$ filter pack $010+090$, lens aperture $f / 5.6$, exposure time 15 sec; development of the film in Ciba-llford Microphen

glacial acetic acid, were adsorbed under shaking onto $40 \mathrm{~g}$ of talc. The suspension was centrifuged $(1000 \mathrm{~g}, 2 \mathrm{~min})$, the talc resuspended in methanol-water $(1+1, v+v)$, and sedimented again; on filter paper the talc layer was completely dry within 10 hours at $35^{\circ}$. The filter with the talc was placed in an Erlenmeyer flask, and $200 \mathrm{~m} /$ of methanol-sulphuric acid $(95+5, \mathrm{v}+\mathrm{v})$ were added for esterification, which was carried out at $37^{\circ}$ in $20 \mathrm{~min}$. Following the addition of $200 \mathrm{~m} /$ of chloroform the solvent mixture was filtered through paper into a separating funnel. The porphyrins which still clung to the talc were cluted completely with chloroformmethanol $(4+1, v+v)$, heated to $40^{\circ}$. The whole porphyrin methyl ester mixture was quantitatively extracted with chloroform against water-methanol. Then the chloroform extract was washed to neutrality with conc. sodium hydrogen carbonate in aqueous solution, dried, and the solvent evaporated (see above).

The mixture of porphyrin methyl esters, containing around $1 \mathrm{mg}$, was redissolved in $1 \mathrm{ml}$ of chloroform. The solution was applied by means of a Pasteur capillary pipette in a band $10 \mathrm{~cm}$ wide to a Silica Gel H plate bearing a layer of $1 \mathrm{~mm}$ thickness. The Camag tank was charged with $100 \mathrm{~m} /$ of the solvent system benzeneethyl acetate-methanol $(85+13+2, \mathrm{v}+\nabla)$, in which the plate was immediately developed. To insure that the lid sealed the chamber tightly, it was weighted down with elongate $1 \mathrm{~kg}$ lead blocks. The separation of the porphyrin esters can be observed by the red fluorescence in UV light $(366 \mathrm{~nm})$. After the first run (Fig. 1 A) the chromatogram was stored, in this case at $-20^{\circ}$, and developed a second time (Fig. 1B) one day later in the same solvent, likewise without presaturation of the chamber. Each red fluorescence zone was removed from the silica gel chromatogram in Figure $1 \mathrm{~B}$ with a special glass aspirator. This consists of heavy glass tubing drawn out at both ends and equipped with a sintered glass filter (pore size $20-25 \mu \mathrm{m}$ ) in a central bulb. The apparatus for drawing up the layers and eluting the porphyrins from them was first described for quantitative recovery of lipids from chromatoplates (11). We have used this type of glass aspirator since 1963 with best results, not only for the quantitative recovery of porphyrin methyl esters $(3,12)$ and lipids $(13,14)$ in the milligram range, but also for microgram quantities both of porphyrin acid methyl esters $(13,15)$ and fatty acid methyl esters (14). Elution of the various substances is carried out within a few seconds under moderate pressure from a cylinder of compressed nitrogen (11). Porphyrin esters are eluted from the silica gel with chloroform or chloroform-methanol $(95+5, v+v)$.

\section{Analytical chromatograpby}

TLC of porphyrin methyl esters at the analytical level is carried out on pre-coated silica gel plates or cards (see under Materials). These plates or cards are first run successively in chloroformmethanol $(2+1, v+v)$ and chloroform-methanol $(1+2, v+v)$ solvent systems up to the upper edge, in order to eliminate impurities. The plates then are dried, and subsequently reactivated by heating at $80^{\circ}$ for $30 \mathrm{~min}$. This pretreatment leads to a better spectrophotometric and fluorometric analysis of the porphyrin esters. The porphyrin mixture is dissolved in $50-100 \mu l$ of chloroform, and applied quantitatively, either in bands $2-4 \mathrm{~cm}$ in width with very fine glass capillaries, or as spots, using self-filling micropipettes (see Materials).

\section{Development of the cbromatograms}

The chromatoplates were developed in the benzene-ethyl acetatemethanol system as shown in Figures 2 and 3. An initial short run in chloroform-methanol $(130+20, v+v)$ for the purpose of forming a new, very thin starting line is useful in achieving a sharp separation of the porphyrins. The individual bands can be seen in Figure 2.

If necessary a cleaner development can be achieved with several systems in the following manner:

1. Chloroform-methanol $(130+20, v+v), 1-2 \mathrm{~cm}$, repeated once; thereafter complete drying in air. A new starting line for porphyrin methyl ester is formed at the solvent front.

2. Petroleum ether (boiling range $\left.40-60^{\circ}\right)$-diethylether $(4+1$, $\nabla+v), 16 \mathrm{~cm}$. Cholesterol ester, triglycerides, waxes, and fatty acid methyl esters run near the front, and are thereby completely separated from the porphyrins.

3. Benzene-cthyl acetate-methanol $(85+13.5+1.5, \nabla+\nabla)$, $8-14 \mathrm{~cm}$. The porphyrins are separated according to the number of methyl ester groups in each.

4. Chloroform-methanol $(100+5, v+v), 2 \mathrm{~cm}$, for sharp separation of hemin dimethyl ester from unidentified material lying at the starting zone. 


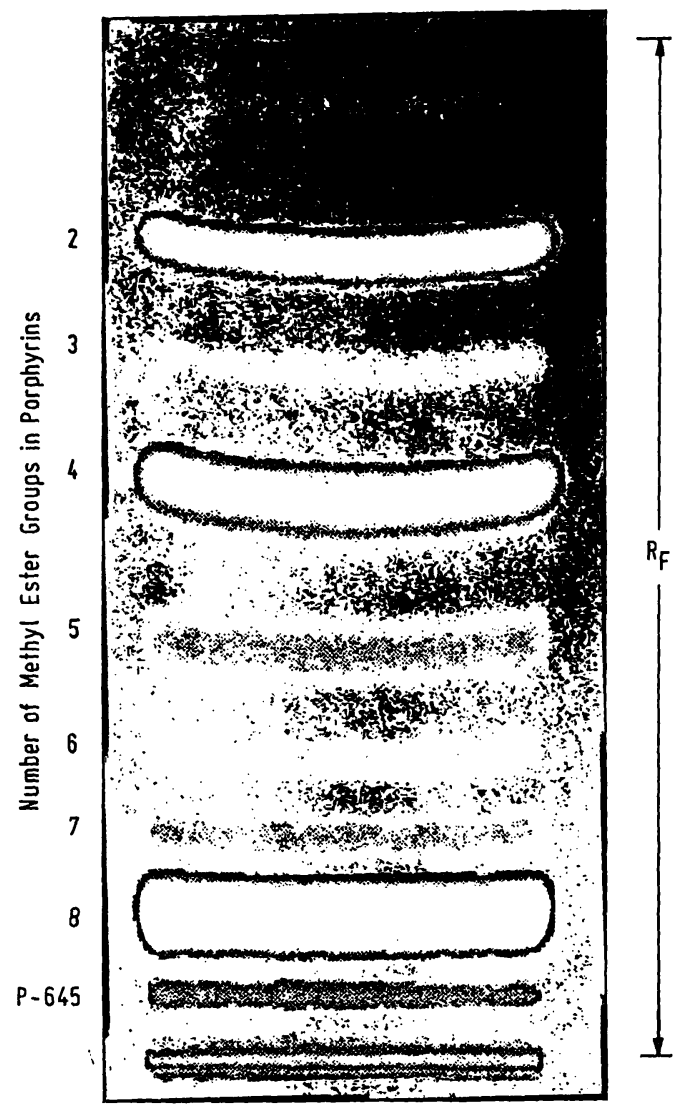

Fig. 2

Separation of total porphyrins as methyl esters (P-ME) from a bacterial extract by TLC on a Silica Gel $F_{25}$ plate $(10 \times 20 \mathrm{~cm})$. Cell suspensions of Achromobacter metalcaligenes, grown under aerobic conditions in a synthetic medium containing lactate as an energy source, synthesize high concentrations of porphyrins from added $\delta$-aminolevulinic acid (here $0.1 \mathrm{~mm}$ ). All the porphyrins of the culture were adsorbed to talc and esterified. After development in the benzene-ethyl acetatemethanol solvent system $(85+13.5+1.5, \mathrm{v}+\mathrm{v})$, the P-ME bands appear as follows, from start to front: P- 645 , uro-, hepta-, hexapenta-, copro-, tricarboxylic-, and proto-P-ME. The chromotogram was photographed under UV light $(366 \mathrm{~nm})$

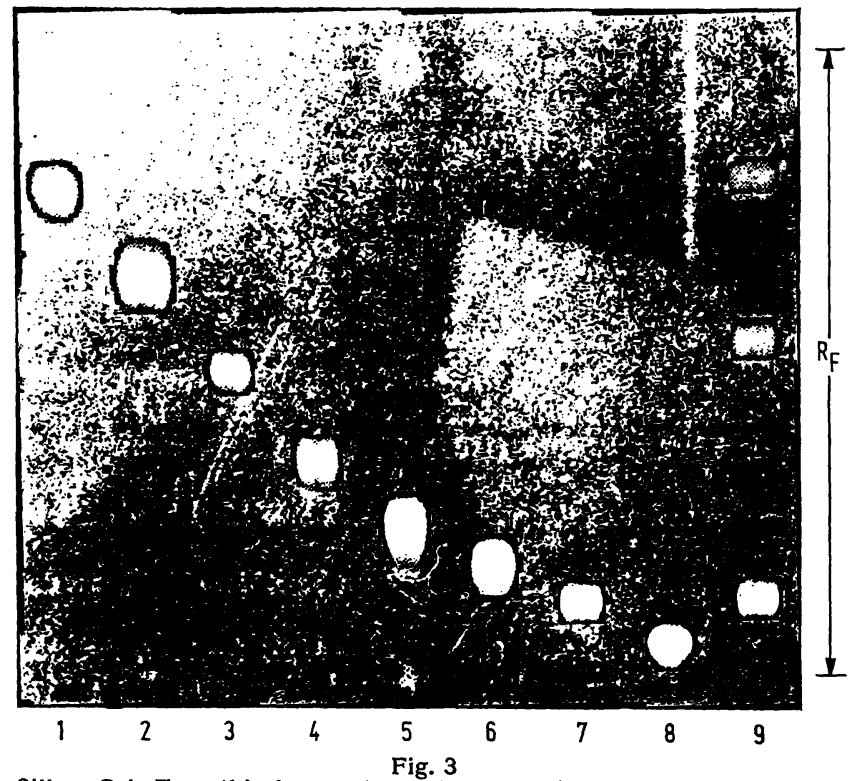

Silica Gel $F_{254}$ thin-layer chromatogram with isolated porphyrin carboxylic acid methyl esters (P-ME) of microbial origin. The chromatographic plate $(20 \times 20 \mathrm{~cm})$ was developed in the benzene-ethy acetate-methanol solvent system $\left(85+13.5+1.5, \mathrm{v}+\mathrm{v}, 21^{\circ}, 40\right.$ P-ME 5 H. PuE, 5 Hes substances, from start to front: Uro-P-I-ME, Copro-P-I-ME, and mato-P-IX-ME. The photograph of the porphyrin thin-layer chromatogram was taken under the following conditions: object-lens Tessar 1iford $F$ P4 ASA 125 , film shutter speed $30 \mathrm{sec}$, and development of the film with Ciba Ilford Microphen

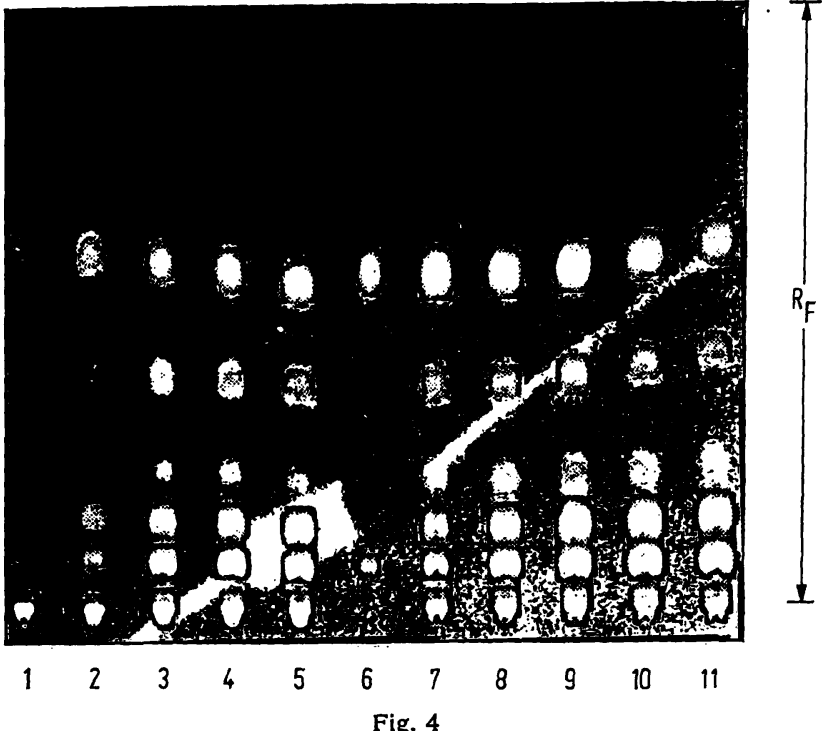

Chromatogram of esterification kinetics of talc-adsorbed prophyrins from the urine of a patient with porphyria.cutanea tarda. $1-5$ esterififrom the urine of a patient with porphyria.cutanea tarda. $1-5$ esterifications with methanol-sulphuric acid $(99+1, v+v)$ at $20^{\circ}$ after 10 min., $1,3,5$, and 8 hours; 6 reference substances, copro- and uroporphyrin methyl esters; $7-11$ esterifications with methanol-sulphuurine sample of $2.5 \mathrm{ml}$ was used in each of the above experiments

\section{Dicarboxylic porphyrins}

Deuteroporphyrin dimethyl ester is separated in the solvent system benzene-ethyl acetate-methanol $(85+13.5+1.5, \mathrm{v}+\mathrm{v})$ from protoporphyrin, which has a lower $R_{\mathrm{F}}$ value (Fig. 5). Mesoand protoporphyrin methyl esters do not separate in this system. Nonetheless, it is possible to differentiate between them on the basis of the different positions of their absorption maxima in spectrophotometry (16). As can be seen in the chromatogram in Figure 5, hematoporphyrin IX dimethyl ester migrates only a short distance from the start; because of its wide separation from the other dicarboxylic porphyrin esters, it is easily distinguished from them. Confusion with porphyrins containing more carboxylic groups, but which behave similarly in chromatography, can be precluded in the following way: With acetylation of the hydroxyl groups in the side-chains, the $R_{F}$ value of the hematoporphyrins

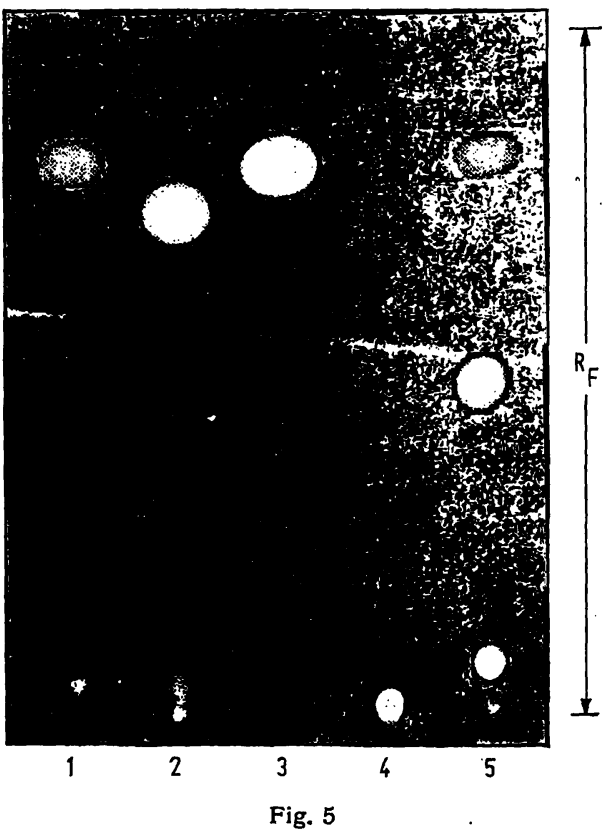

Chromatogram of dicarboxylic porphyrin methyl esters on a silica gel aluminium card $(95 \times 180 \mathrm{~mm}$, layer thickness $0.2 \mathrm{~mm})$, developed in the benzene-ethyl acetate-methanol solvent system. The position of the substances: 1 protoporphyrin IX, 2 deuteroporphyrin IX, 3 mesoporphyrin IX, 4 hematoporphyrin IX, 5 uro-, copro-, and protoporphyrin methyl esters of the isomer in I series 
IX dimethyl ester increases considerably (12); in contrast, the $R_{\mathrm{F}}$ values of the porphyrins without hydroxyl groups remain unchanged under these conditions.

\section{Isomers of the I and III series of copro- and uroporpbyrin}

The adaptation for TLC of methods for separating both coproporphyrin and uroporphyrin isomers of the I and III series, originally involving paper chromatography (16), has been mentioned in a previous paper in this journal (17). The critical aspects of this method are discussed and summarized in a review article (2).

\section{Rapid methods}

Rapid separations are achieved on small $(30 \times 90 \mathrm{~mm})$ silica gel cards (layer thickness $0.2 \mathrm{~mm}$ ), which have been cut from $95 \times$ $180 \mathrm{~mm}$ TLC cards (Riedel-de Haën 37351). Thesc "microcards" are developed in micro-tanks (Camag), using solvent systems consisting mainly of chloroform (analytical grade, containing 1\% ethanol), to which small volumes of methanol or ethyl acetate are added, so that the porphyrins may be separated from one another. The chromatograms in Figure 6 show the variation of $R_{F}$ in response to the amount of ethyl acetate added to the chloroform. Here the porphyrin mixture in chloroform solution was applied by means of very thin glass capillaries. However, it is casier and faster to apply the solution with self-filling micro-pipettes (Camag).

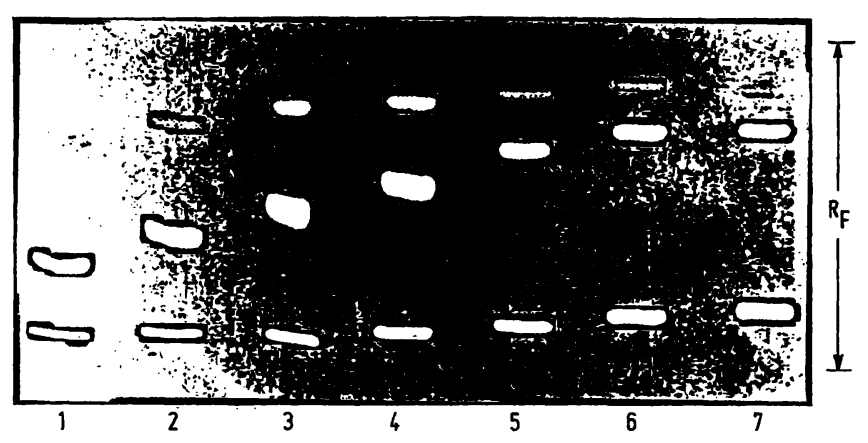

Fig. 6

Rapid separation of porphyrin methyl esters in micro-tanks on silica gel aluminium chromatocards $(30 \times 90 \mathrm{~mm})$. Solvent systems chloroform (containing $1 \%$ ethanol)-ethyl acetate $(v+v): 1(95+5)$, $2(93+7), 3(90+10), 4(88+12), 5(85+15), 6(80+20)$, and $7(75+25)$

After the samples have been applied a new starting point was formed by dipping the lower edge of each card into a small open Petri dish (diameter $50 \mathrm{~mm}$ ) containing chloroform-methanol $(130+20, v+v)$. Following this, the methanol must be allowed to evaporate completely from the silica gel. The micro-tanks are each filled with $5 \mathrm{ml}$ of one of the solvent systems described in the legend to Figure 6. The chromatographic cards are immediately developed in this system, running $12 \mathrm{~min}$ at $20^{\circ}$ to a height of $8 \mathrm{~cm}$. The solvent systems 2 to 5, as listed in the legend to Figure 6, give full separation within $5 \mathrm{~min}$ after only $5 \mathrm{~cm}$, comparable to the results in system 1 . When the chromatocards were spotted with self-filling micropipettes, no tailing was observed in amounts up to $2 \mu \mathrm{g}$ of the porphyrin esters.

\section{Detection and documentation}

The porphyrins on the chromatogram are recognizable by their red fluorescence in ultraviolet light $(3500-3660 \AA)$. The efficiency with which porphyrins are made visible in chromatograms on the basis of their fluorescence under long-wave UV radiation depends upon the properties of the lamp. Mercury high-pressure lamps (e. g., "Fluotest forte" from Original Hanau Quarzlampen, Hanau, B. R. D.) are the most effective. With such lamps as little as $2 \mathrm{ng}$ of porphyrin may be seen on a silica gel area of $1 \mathrm{~cm}^{2} 0.20 \mathrm{~mm}$ thick. The detection of the porphyrins which fluoresce in red may be intensified by spraying the chromatograms with iso-octane (16), petroleum ether, or benzene.

In order to obtain permanent records of the chromatograms a special technique has been described for the photographic repro- duction of porphyrins and hemin in silica gel thin-layer chromatograms under long-wave ultraviolet light (18). Standard conditions, including equipment (camera, lenses, UV lamps), specific filters, and light values, permit the registration of porphyrins through their own fluorescence. Even minimal amounts, i. c., up to $1 \mathrm{ng}$, can be captured in color as well as in black and white, both on negative and reversal films. The photographs allow an approximate cstimation of the relative concentrations of porphyrins present in the chromatogram.

\section{Fluorometric scanning of chromatograms}

Direct evaluation of porphyrin bands or spots on a chromatogram is performed using the principle of fluorometry on the TLC Scanner (Camag, Muttenz, Switzerland). For the analysis of porphyrins the Turner filter fluorometer model 111 was equipped with the red-sensitive photomultiplier HTV-R136 (Hamamatsu TV Co., LTD, Japan); the fluorometer was modified with the Camag TICC Scanner, and connected to a Hitachi recorder QPD$33,10 \mathrm{mV}$.

The fluorescence scanning conditions for silica gel chromatograms of porphyrins are: light source $110-853$, primary filter 813 , secondary filter 820; position of the diaphragm aperture at primary filter " $30 \mathrm{x}$ "; velocity of the TLC Scanner 1 or $2 \mathrm{~cm} / \mathrm{min}$. The intensity of the primary light is regulated with gray filters and/or adjustment of the width of the excitation slit in order to achieve an optimal resolution, i. c., separation of the peaks, of which the highest should take up nearly the full span of the recording paper (Fig.7). The registered fluorescence intensities are evaluated geometrically by multiplying the height of each peak by its width at half the height (Tab. 1), provided the peak is nearly symmetrical.
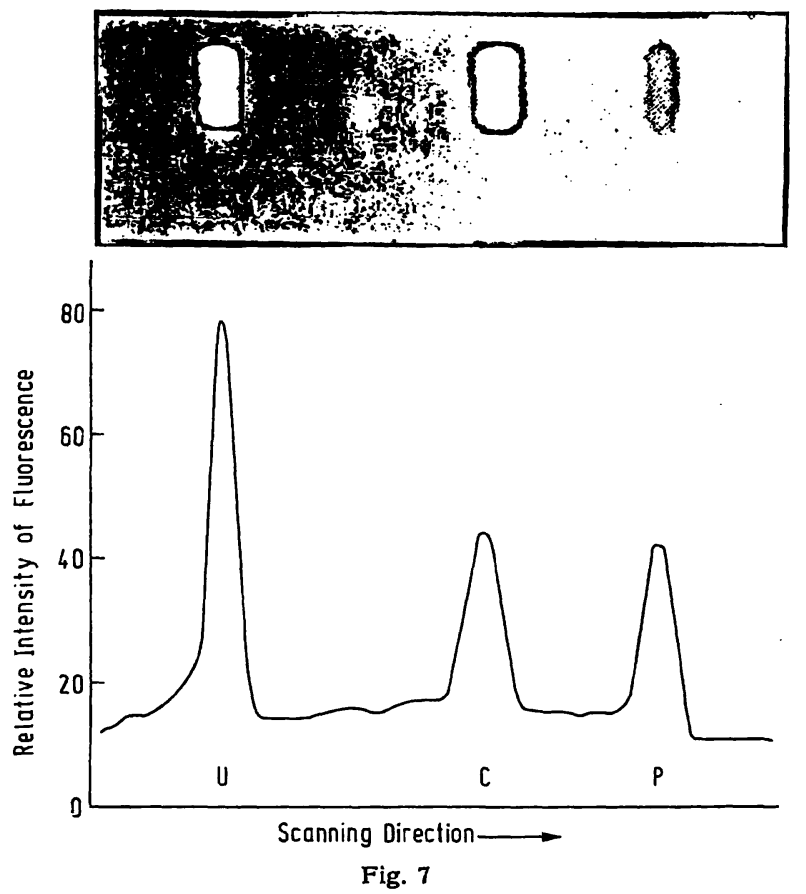

Silica gel thin-layer chromatogram with methyl esters of uroporphyrin III, coproporphyrin III, and protoporphyrin IX, developed in benzeneethyl acetate-methanol $(85+13.5+1.5, v+v)$, and the corresponding fluorescence scanning chart of the same chromatogram, recorded on the Camag-Turner TLC-Scanner. The geometric measurements of the peak areas are listed in Table 1

\section{Spectrophotometric analysis}

The simplest method, although not the most sensitive, is the spectrophotometric analysis of a chloroform solution of the porphyrin methyl ester after the esters have been eluted out of the silica gel with chloroform. The concentration is calculated on the basis of the absorption in the Soret band (see Tab. 1). In chloroform solution the individual porphyrin methyl esters have the following millimolar extinction coefficients: Proto407.5 165, 
Tab. 1

Comparison of the analysis of a thin-layer chromatogram (shown in Fig. 7) containing porphyrin methyl esters, by means of fluorescence scanning versus spectrophotometric measurement in chloroform solution following elution of the esters from the silica gel layer

\begin{tabular}{|c|c|c|c|c|c|}
\hline \multicolumn{2}{|c|}{ Materials } & \multirow{2}{*}{$\begin{array}{l}\text { Porphyrin } \\
\text { methyl esters }\end{array}$} & \multirow{2}{*}{$\begin{array}{l}\text { Total amount } \\
(\mu \mathrm{g}) \text { recovered } \\
\text { from TLC }\end{array}$} & \multicolumn{2}{|c|}{ Porphyrins (\%) } \\
\hline $\begin{array}{l}\text { Source of the } \\
\text { porphyrins }\end{array}$ & $\begin{array}{l}\text { Pre-coated } \\
\text { plates (cards) }\end{array}$ & & & $\begin{array}{c}\text { by } \\
\text { Spectrophotometry }\end{array}$ & $\begin{array}{c}\text { by } \\
\text { Fluorometry }\end{array}$ \\
\hline $\begin{array}{l}\text { Reference } \\
\text { substances }\end{array}$ & $\begin{array}{c}\text { TLC-plate } \\
\text { Silica Gel } \\
\text { F }_{284}\end{array}$ & $\begin{array}{l}\text { Proto-IX } \\
\text { Copro-III } \\
\text { Uro-I }\end{array}$ & 1.91 & $\begin{array}{l}25.2 \\
22.5 \\
52.3\end{array}$ & $\begin{array}{l}26.6 \\
28.0 \\
45.4\end{array}$ \\
\hline
\end{tabular}

copro $_{399.5} 180$, penta 401.0189 , hexa 402,5198 , hepta 404.0207 , and uro 405.5216 . Further data, especially for dicarboxylic and other porphyrins, have been collected by FALK (16). The lower limit of accuracy of measurement on a non-expended scale for the porphyrin methyl esters in chloroform solution lies at $0.1 \mu \mathrm{g}$ (d = $1 \mathrm{~cm}$, measured volume $1 \mathrm{ml}$ ).

The transformation of the porphyrin ester into metal complexes through the insertion of, for example, copper or zinc into the central position of the cyclic tetrapyrrole brings with it a significant increase in the molar absorption in the Soret band. The copper chelates are obtained after the solvent has been evaporated and the porphyrin methyl esters dissolved in a solution of $\mathrm{Cu}$ (II)acetate $0.1 \%(w / v)$ in chloroform-methanol $(19+1, v+v)$. Zinc chelates may be obtained in a similar manner. Following complete removal of chloroform, the porphyrin methyl ester is dissolved in solution of $\mathrm{Zn}$ acetate $0.5 \%(\mathrm{w} / \mathrm{v})$ in chloroform-methanol $(19+1, v+v)(19)$. Porphyrin esters in analytical amounts are converted into $\mathrm{Cu}$ chelates within $10 \mathrm{~min}$., and into $\mathrm{Zn}$ chelates within $30 \mathrm{~min}$. at room temperature. Under long-wave UV light the $\mathrm{Zn}$ chelates exhibit an orange-colored fluorescence, in contrast to the $\mathrm{Cu}$ chelates, which do not fluoresce in the visible range.

\section{Results}

As shown in an earlier paper (3), the precision and therefore the preparative and analytical application of the method for separating porphyrins in the form of their methyl esters by silica gel thin-layer chromatography has been increased. In addition, it was possible to develop modifications for a rapid method. In principle the porphyrins are separated according to the number of methyl ester groups in the molecule (Figs. 1-4). The rapid methods, which permit a separation within $10 \mathrm{~min}$ (Fig. 6), are preferable for the biochemical diagnosis of disturbances in porphyrin metabolism. As is shown in Figures 4 and 12, only $2 \mathrm{ml}$ of urine are necessary for a diagnosis based on findings in thin-layer chromatography. Similarly, a porphyrin methyl ester extract from $2 \mathrm{ml}$ of normal urine is sufficient for demonstrating coproporphyrin satisfactorily by use of the rapid method. The chromatograms or cards pre-coated with abrasionresistant silica gel layers can be kept for several years as original documents, provided they are stored under $0^{\circ}$.

Tab. 2

Determination of the porphyrins from the chromatogram shown in

\begin{tabular}{lcc}
\hline $\begin{array}{c}\text { Substance } \\
\text { eluted }\end{array}$ & $\begin{array}{c}\text { Soret absorption } \\
\text { maximum (nm) } \\
\text { in chloroform }\end{array}$ & $\begin{array}{c}\text { Amount }(\mu \mathrm{g}) \\
\text { recovered }\end{array}$ \\
\hline Proto & 408 & 0.41 \\
Tricarboxylic & 404 & ca. 0.07 \\
Copro & 400 & 0.59 \\
Pentacarboxylic & 401 & 0.22 \\
Hexacarboxylic & 402 & 0.15 \\
Heptacarboxylic & 404 & 0.72 \\
Uro & 406 & 17.58 \\
P-645 & 396 & ca. 0.20 \\
\hline
\end{tabular}

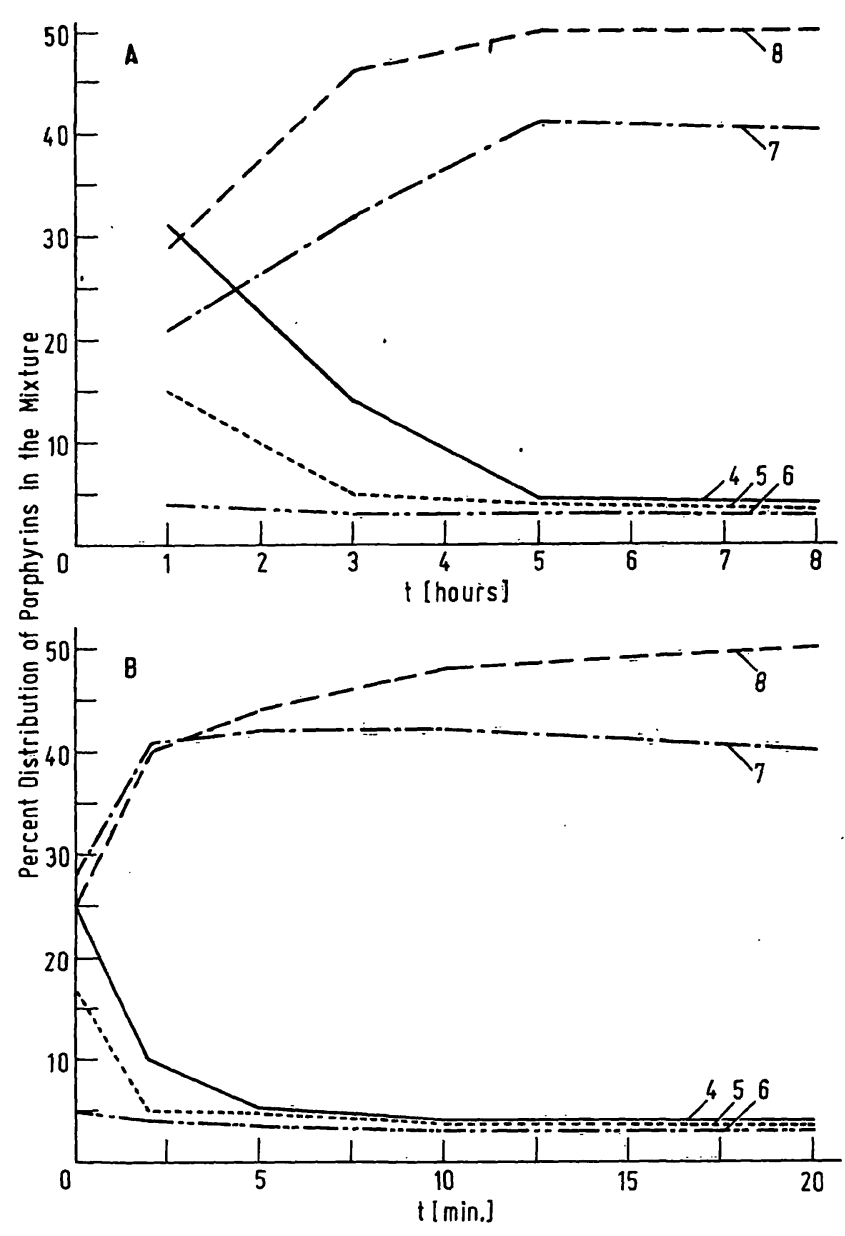

Fig. 8

Esterification of the porphyrins as a function of the number of carboxyl groups in each, time and temperature of the reaction, and concentration of methanol-sulphuric acid. Source of the porphyrins: urine from a Porphyria cutanea tarda patient (see Fig. 4). A: Esterification at $20^{\circ}$ with methanol-sulphuric acid $(99+1, v+v)$. B : Esterification of carboxyl groups in each porphyrin

Esterification of the porphyrin is equally effective with 5 vol. $\%$ methanol-sulphuric acid for $20 \mathrm{~min}$ at $35^{\circ}$, or with 1 vol. $\%$ methanol-sulphuric acid for 8 hours at $20^{\circ}$ (Fig. 8). As is to be seen on chromatograms from these studies (Fig. 4), the kinetics of esterification of the total porphyrins in the two experimental series is different (Tab.3). The rate of esterification of the individual porphyrins depends upon the number of carboxyl groups per molecule. The reaction proceeds very similarly under various conditions (Fig. 8). The ratio of the volume of urine from which the porphyrins have been adsorbed (total porphyrin content $1.1 \mu \mathrm{g} / \mathrm{m} /$ ) to the volume of the esterification mixture was 2.5:1. Parallel experiments under these conditions showed esterification to be practically complete with 1 vol. \% methanol-sulphuric acid at $35^{\circ}$ after $90 \mathrm{~min}$, as well as with 
Tab. 3

Total esterification (\%) of a porphyrin mixture under various conditions

\begin{tabular}{lccrrr}
\hline $\begin{array}{c}\text { Time (hours) } \\
\text { vol. \% methanol- } \\
\text {-sulphuric acid }\end{array}$ & 0.6 & 1 & 3 & 5 & 8 \\
$\begin{array}{c}20^{\circ} \\
\text { Time (min) }\end{array}$ & Traces & 3 & 28 & 65 & 100 \\
$\begin{array}{l}\text { vol. \% methanol- } \\
\text {-sulphuric acid } \\
35^{\circ}\end{array}$ & 0.5 & 2 & 5 & 10 & 20 \\
\hline
\end{tabular}

Tab. 4

The influence of shaking upon the esterification of porphyrins from porphyric urine adsorbed on talc

Conditions of the experiment: $5 \mathrm{ml}$ urine, $\mathrm{pH} 4.5,0.2 \mathrm{~g}$ talc, addition of $2 \mathrm{ml}$ of $\mathrm{CH}_{3} \mathrm{OH}-\mathrm{H}_{2} \mathrm{SO}(95+5, \mathrm{v}+\mathrm{v}), 15$ min at $35^{\circ}$, stationary or oscillated horizontally at a frequency of $300 / \mathrm{min}$. Analysis:
direct fluorometric analysis of the porphyrin esters in the thin-layer chromatogram, using the Camag-Turner TLC-Scanner

Percent distribution of pophyrins in the mixture according to the number of carboxyl groups

\begin{tabular}{lrrrrr}
$\begin{array}{l}\text { Esterfication } \\
15 \text { min. at } 35^{\circ}\end{array}$ & 4 & 5 & 6 & 7 & 8 \\
\hline stationary & 4.7 & 4.4 & 2.8 & 40.1 & 48.0 \\
oscillating & 4.5 & 4.1 & 3.0 & 38.8 & 49.6 \\
\hline
\end{tabular}

5 vol. $\%$ methanol-sulphuric acid at $20^{\circ}$ after 4 hours. Shaking had no effect upon the esterification (Tab. 4). The analysis of the porphyrins in these esterification experiments was carried out on thin-layer chromatograms using fluorometry. The percent distribution of the individual porphyrins in the course of esterification, based on the relative areas under the peaks, is summarized in the curves in Figure 8. No destruction of the porphyrins with 4 to 8 carboxyl groups was found during esterification under conditions of moderate warmth, as compared with those at $20^{\circ}$, either in these experiments (Figs. 4 and 8), or after esterification with 5 vol. $\%$ methanol-sulphuric acid for 10 hours at $35^{\circ}$. Protoporphyrin is practically completely esterified within $5 \mathrm{~min}$ in 5 vol. \% methanol-sulphuric acid at $20^{\circ}$; after $15 \mathrm{~min}$ at $35^{\circ}$, neither qualitative changes nor reduction of yield occurred.

The methods described in this paper were applied exclusively and on principle to dried biological samples or isolated substances. Minute traces of water do not disturb the esterification, but even 5-10\% water in the methanol leads to substantial losses of yield (about 30\% of the copro- and $20 \%$ of the uroporphyrin).

In preparative work, it was possible to separate around $2 \mathrm{mg}$ of porphyrin methyl ester into components bearing 8 to 2 carboxyl groups, using a $20 \times 20 \mathrm{~cm}$ plate with a layer $1 \mathrm{~mm}$ thick. If a methyl ester mixture is applied in which one of the porphyrins has been previously concentrated, the capacity of the plate is considerably greater (12). As shown in Figure 1, separation is effected of uro- and coproporphyrin, and of the intermediary 7-, 6-, and 5-COOH porphyrins, which are mixtures of the isomers I and III series. The red fluorescent zones lying below the uroporphyrin methyl ester were eluted and esterified once again. After recovery of the methyl ester in the usual way, the material was rechromatographed. Chromatography and spectrophotometric analysis of the eluted substances showed that two of these bands, seen in Figure 1, consist of incompletely esterified uro- and 7$\mathrm{COOH}$ porphyrins. This finding is in agreement with the observation of other investigators (20) in their reports on the isolation of urinary porphyrins. Beyond this, the porphyrin mixture visible below uroporphyrin in the chromatograms (Figs. 1, 4, and 11) contains a whole series of porphyrin substances with unusual absorption maxima, along with porphyrin zinc complexes, the occurrence of which is typical for Porphyria cutanea tarda.

If one wishes take advantage of ready-made thin-layer plates, cards, or sheets for isolating porphyrins on a microgram scale, e. g., to be used as reference substances, the Camag plates are especially suitable, since the layer is easier to remove than that of other pre-coated silica gel TLC brands. In addition, the elution of the porphyrins from the sorption layer takes place with unusual rapidity in comparison with other forms of silica gel. Applied in a band $16 \mathrm{~cm}$ wide, $100-200 \mu \mathrm{g}$ of a mixture can be separated for use as test substances. One needs no more than $10 \mathrm{ng}$ of each reference substance, applied as a spot, for one chromatogram. We prepare a mixture of proto-, copro- and uroporphyrin methyl esters, which is stored at $-10^{\circ}$.

A chromatogram on a pre-coated silica gel plate run in the standard benzene-ethyl acetate-methanol system $(85+13.5+1.5, v+v)$ is shown in Figure 2. On it a complex porphyrin mixture is separated. The porphyrins were extracted from a culture of Acbromobacter metalcaligenes, which produces porphyrins containing eight to two carboxylic groups from added $\delta$-aminolevulinic acid (8) (a known porphyrin precursor), and a hitherto unknown substance. The latter was also isolated and appears at position 8 in Figure 3 after rechromatography. The amounts of porphyrin in the individual bands shown in Figure 2, eluted and then analyzed in chloroform solution by spectrophotometry, are given in Table 2.

Some of the substances were pooled from two plates, such as those in Figure 2, and rechromatographed; the chromatogram is presented in Figure 3. The samples were applied to the plate with self-filling micro-pipettes (Camag). Each spot contains ca. $0.1-0.4 \mu \mathrm{g}$ of porphyrin. During the development no tailing was observed. In the substance in position 8 of Figure 3, no hydroxyl groups were to be detected in the side chains (16), as would be characteristic of hematoporphyrin IX (12). The shade of red fluorescence under UV light $(366 \mathrm{~nm})$ does not differ from that of other porphyrins. However, the fluorescence emission maximum of the substance in chloroform solution lies at $650 \mathrm{~nm}$. Preliminary spectrophotometric analysis of this substance reveals only four absorption maxima: at 396 (16), 495 (1), 595 and 645 (3) $\mathrm{nm}$. The relative intensities of absorbance are shown in parentheses. Because of the relatively strong absorption band at $645 \mathrm{~nm}$, the substance was previously denoted "porphyrin 645". Since biosynthesis of "porphyrin 645" is dependent on the concentration of the added precursor, and varies according to the rate of synthesis of uroporphyrin, it is assumed that "porphyrin 645" is not a degradation product. 


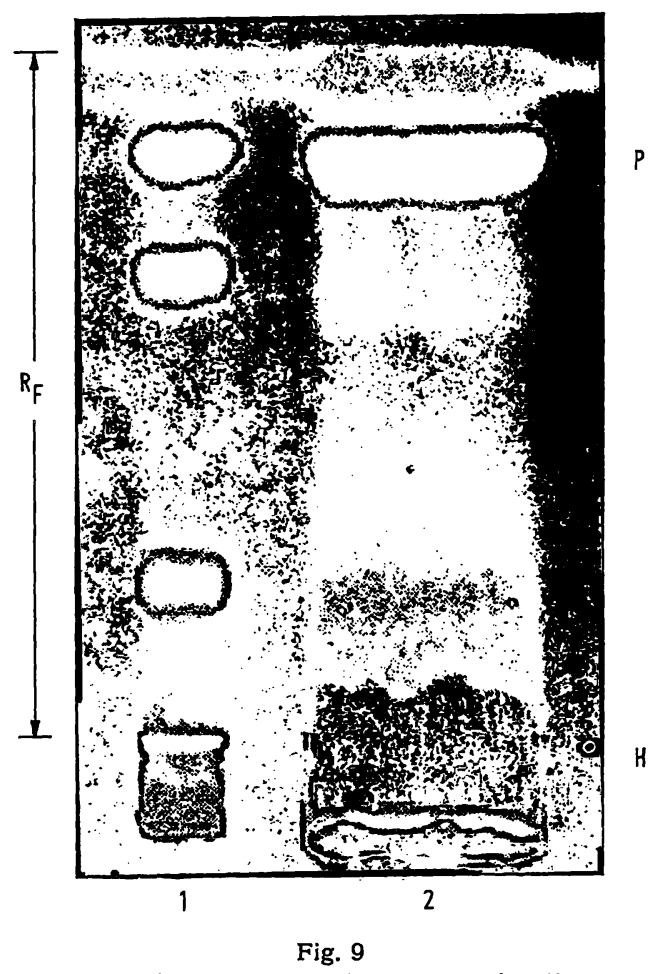

Silica Gel DSF-A thin-layer chromatogram showing the separation of erythrocyte protoporphyrin $(P)$ from protohemin $(H)$. The substances were obtained from $0.1 \mathrm{ml}$ of lyophilized erythrocytes of a patient with erythropoietic . protoporphyria (2). For reference substances (1) see legend to Fig. 3 . Before the run a new starting line was formed in the chloroform-methanol system. The data for photographing the chromatogram are identical to those given in the legend to Fig. 3, except that the exposure time was $4 \mathrm{~min}$

In the analysis of erythrocytes (Fig. 9), hemin, which is split from hemoglobin during esterification, was esterified parallel to free protoporphyrin, as can be seen in a sample from a patient with erythropoietic protoporphyria (4). In the solvent system used, hemin methyl ester migrates only slightly, and only when present in great amounts in the porphyrin extract solution (Fig. 9). Hemin can be recognized as a brownish-black spot or, if present in very small amounts $(<1 \mu \mathrm{g})$, demonstrated with 0 -tolidine reagent (16). A more extensive methodological study on the TLC separation of porphyrins, hemin, and lipids on Silica Gel H plates for determination of erythrocyte porphyrins in form of their methyl esters has shown the chloroform extract after esterification of porphyrins contain fatty acid methyl esters, cholesterol, small amounts of sphingomyelin, traces of glycerophosphatides, and large amounts of hemin methyl ester (15). The lipids were detected by TLC and gas-liquid chromatography. During esterification of erythrocyte porphyrins and protohemin the fatty acids of glycerophosphatides are trans-esterified to methyl esters. This was shown in gas-chromatographic analysis of these fatty acid methyl esters, recovered from the chromatogram, in comparison with the analysis of those prepared by rapid alkali-catalyzed trans-esterification of isolated erythrocyte glycerophosphatides (15) with sodium methylate (14). On the chromatogram the fatty acid methyl esters lie at the front, and can be seen as light blue zones under UV light (366 nm).
The prosthetic group of cytochrome $b$ is involved along. with the porphyrins in esterification, extraction, and chromatography of the porphyrin methyl esters. It then occurs in the form of protohemin methyl ester, which is separated from the porphyrin methyl esters in chromatography (see Experimental Procedures) and analyzed on the basis of the difference spectrum (reduced minus oxidized) (21).

In a previous study on fluorescence scanning of porphyrin methyl esters in thin-layer chromatograms, it has been shown (22) that quantitive analyses are possible, based on reproducibility of $1-6 \%$ related to the standard deviation from the mean (variation coefficient). The studies were continued using the Camag-Turner TLCScanner, the design and operation of which are described elsewhere (23).

The equipment for fluorometric scanning of porphyrin methyl ester separated on ready-made abrasionresistant analytical silica gel cards or plates is described in the experimental part of this paper. In Figure 7 a thin-layer chromatogram with reference spots of proto-, copro-, and uroporphyrin is shown in conjunction with its corresponding fluorescence scanning chart (Tab. 1). Under the conditions described under Procedures, a linear relationship was found between peak area and porphyrin concentration, as well as between peak area and the variation of the width of the excitation slit between zero and $3.5 \mathrm{~mm}$. The height of the slit of the TLC-scanner is fixed at $15 \mathrm{~mm}$. On the basis of these

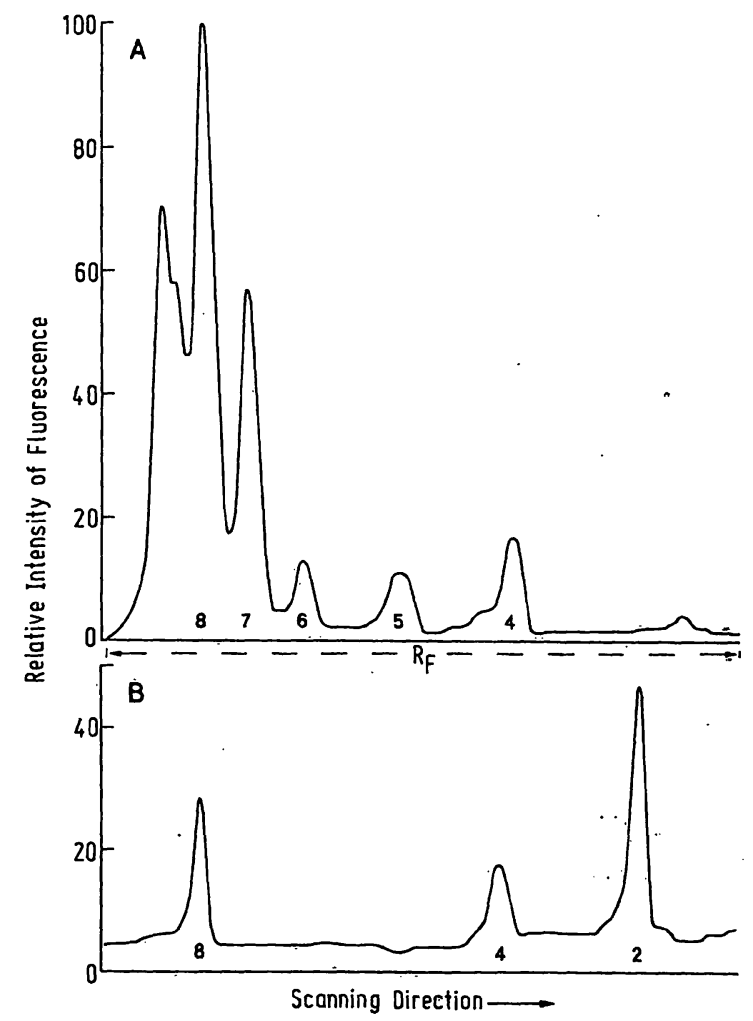

Fig. 10

The distribution of the porphyrins of a urine sample, as recorded in fluorescence scanning (A) of the chromatogram No. 1, shown in Fig. 11, in comparison with the reference substances (B). The width of the excitation slit for $A$ was 1.95 , and for $B 2.6$. 4 to 8 denote the number of methyl ester groups in the porphyrins 


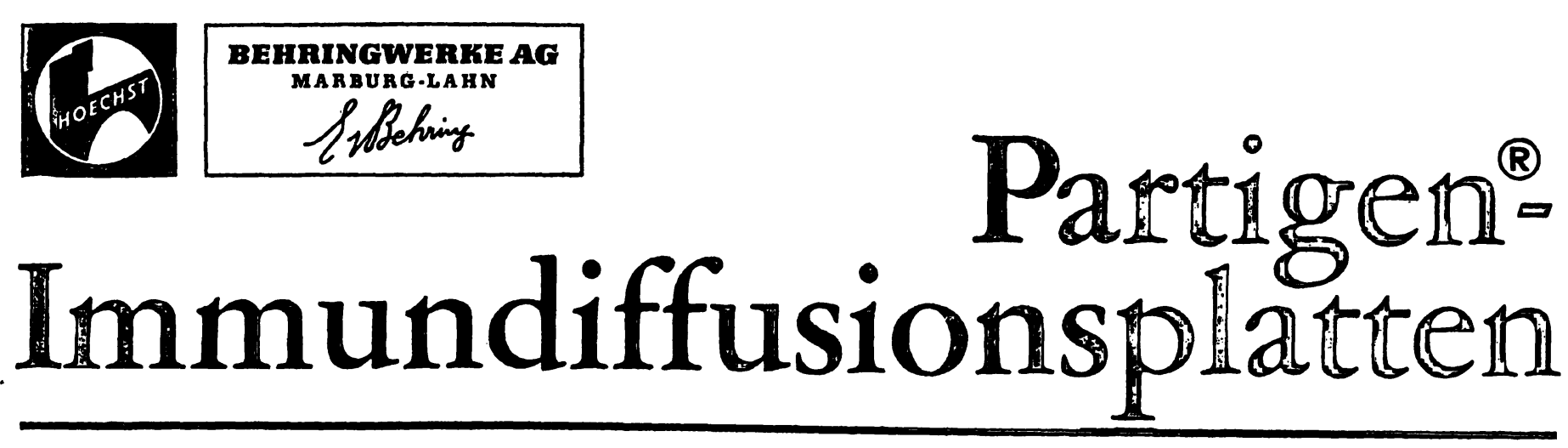

Antiserum-haltige Agargelplatten Behringwerke für quantitative Plasmaprotein-Bestimmungen
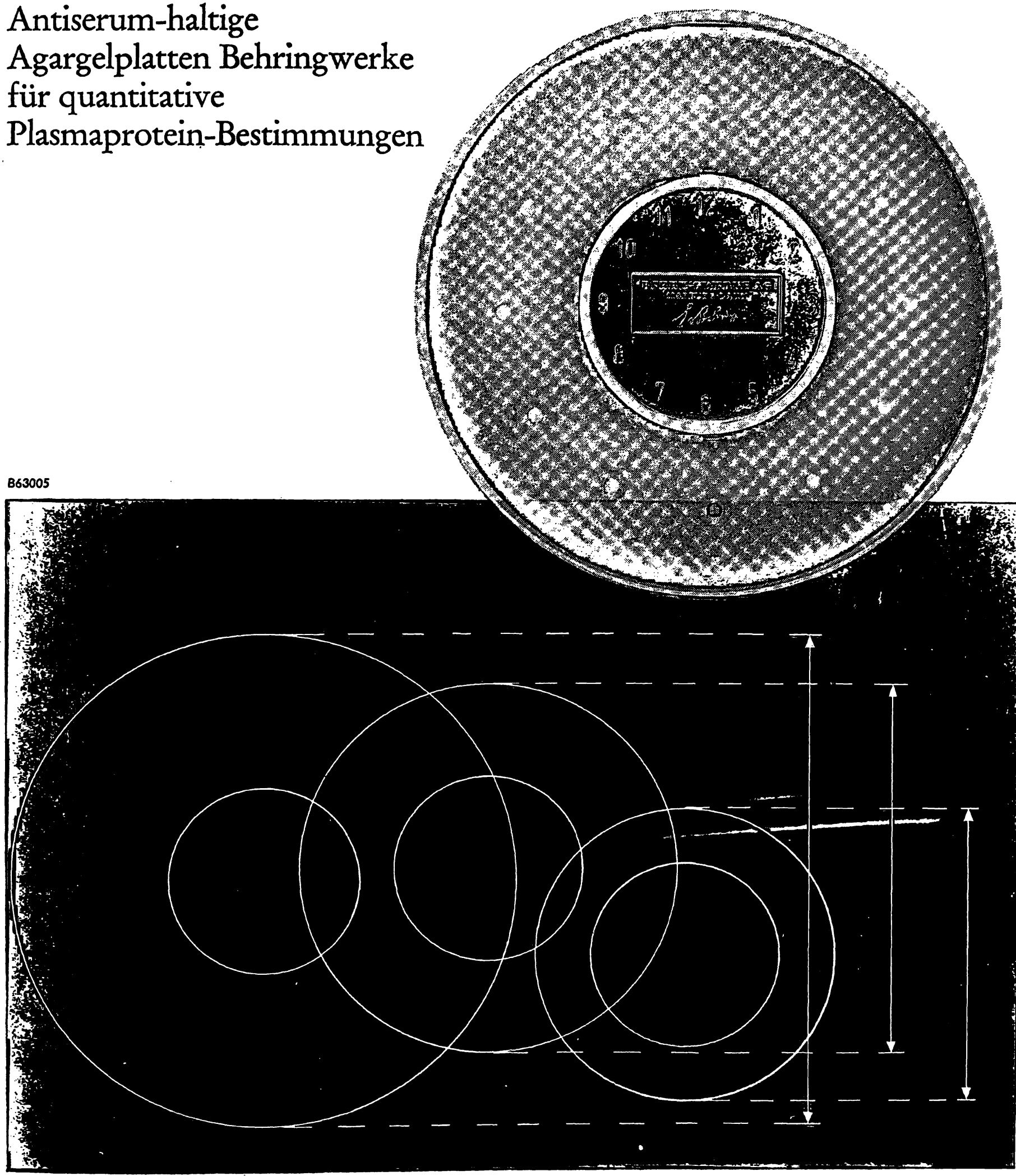
Original Frankfurt - nach Wieland und Pfleiderer - lösen auch schwierigste elektrophoretische Trennaufgaben.

Joule'sche Wärme entsteht bei jeder Elektrophorese $*$, im Bereich Null bis 3000 Volt genau so, wie im Spannungssektor Null bis $\mathbf{5 0 0}$ Volt. Es genügt nicht, sie zu kontrollieren - man muß sie beherrschen.

Wir machen das bei allen Pherographen mit einem fein regelbaren Kühlsystem. Die Trennergebnisse werden dadurch reproduzierbar.

\section{PHEROGRAPH MINI 68 TISCHMODELL}

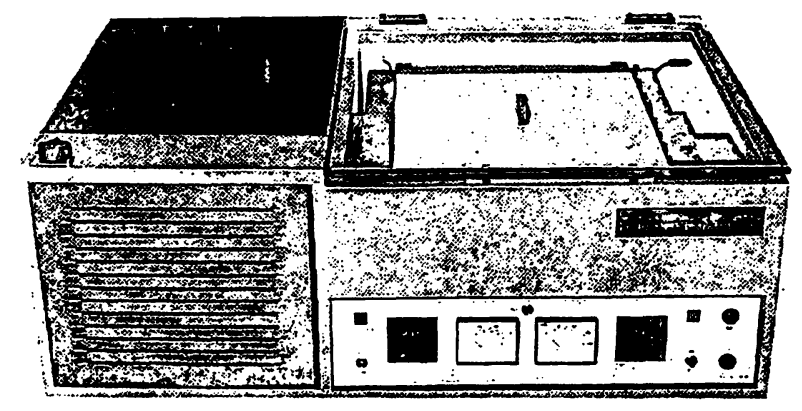

* gleichgültig, ob es sich um das Modell 64 mit zwei Trennkammern, das Modell MINI 65 mit einer Trennkammer, oder um das neue Tischmodell (Abbildung) handelt. Alle besitzen dasselbe bewährte Kühlsystem.

Unser Prospekt HNE 69 sagt viel mehr über Pherographen und gibt Ihnen Anregungen.

WISSEN SCHAFTLICHE APPARATE

\section{HORMUTH-VETTER}

6908 Wiesloch/Bd., Postfach 1348, Tel. 06222/21 47 6900 Heidelberg 1, Postfach 750, Tel. 0622120045
ARBEITSMETHODEN

DER MODERNEN NATURWISSENSCHAFTEN

Herausgegeben von Prof. Dr. Kurt FrsCHBECK

\section{Pataki}

\section{Dünnschichtchromatographie}

in der Aminosäure- und Peptidchemie

Von Dr. phil., Ing. Chem. Grörgy PatakI

Oktav. Mit 128 Abbildungen, 52 Tabellen, 1 Ausschlagtafel, 463 Literaturangaben. XX, 250 Seiten. 1966. Plastikeinband DM 38,-

Das Buch ist empfehlenswert: es stellt für jeden, der au: diesem Gebiet arbeitet, eine wertvolle Hilfe und einer guten Ratgeber für die Praxis dar. Die Erfahrung des Verfassers bewirkt eine solide Auswahl und klare Inter. pretation der Methoden wie deren Möglichkeiten.

Zeitscbrift für Klinische Chemi

\section{Maurer}

\section{Disk-Elektrophorese}

Theorie und Praxis der diskontinuierlichen Polyacrylamdidgel-Elektrophorese

Von H. RaIner Maurer

Mit einem Geleitwort von E. HECKER

Oktav. XVI, 221 Seiten. Mit 82 Abbildungen, 15 Tabellen, 1 Ausschlagtafel und 578 Literaturangaben 1968. Plastikeinband DM 36,-

Die Monographie stellt eine abgerundete Übersicht über das gesamte Gebiet der Disk-Elektrophorese dar. Das Erscheinen dieses Werkes ist sehr zu begrüßen, da die Trennungen von Proteinen und anderen diversen Polymeren mit der Disk-Elektrophorese eine wachsende Bedeutung in den verschiedensten Fachgebieten erlangen. Die theoretischen Grundlagen sind kurz, einfach und präzise dargestellt. Daneben wird auf umfangreichere Abhandlungen verwiesen.

Der praktische Teil des Buches steht im Vordergrund. Es werden die Methodik der analytischen Disk-Elektrophorese und die präparative Polyacrylamidgel-Elektrophorese abgehandelt. Besonders hervorzuheben sind die straffe Gliederung, die gut gestalteten Abbildungen und Tabellen, die verständlichen Arbeitsvorschriften, die Einschätzung der Vor- und Nachteile der einzelnen Verfahren und die Hinweise auf Fehlermöglichkeiten.

Das Ärtliche Laboratorium, Berlin

Walter de Gruyter \& Co $\cdot$ Berlin 
results, quantitative methods for analytical thin-layer chromatography of porphyrin esters can be worked out, using direct fluorometric measurements from the chromatograms. Chromatograms with sharp separations of porphyrins are scanned, giving fluorescence charts which may

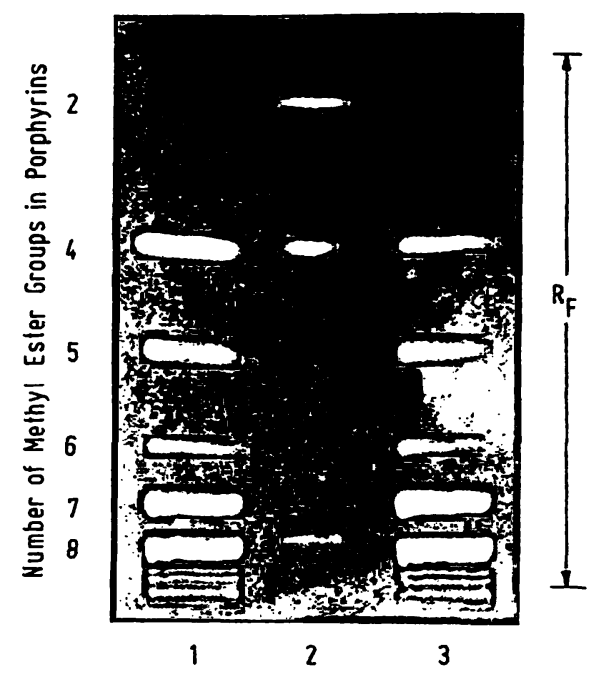

Fig. 11

Thin-layer chromatogram using DC aluminium cards SI (Riedel-de Haen 37351 ). The porphyrins are from two urine samples (1 and 3 , $10 \mathrm{ml}$ each), taken on different days from the same patient with Porphyria cutanea tarda. They exhibit only slight differences in the concentration of the individual porphyrins, which were separated as methyl esters and recorded by photography as described in the legend to Fig. 3. Sample 1 contains relatively more coproporphyrin and somewhat less heptacarboxylic- and uro-porphyrin. Fig. 10 shows the fluorescence scanning chart of this separation. As is evident in a comparison to the positions in the chromatogram of the reference porphyrins uro I, copro III, and proto IX methyl esters (2), this human urine contained no dicarboxylic porphyrins. Before developing the chromatocard in the benzene system, a sharp starting line was formed by a short run, repeated once or twice, exactly up to the upper limit of the applied material, in the chlorofrom-methanol solvent system $(130+20, v+v)$, followed by thorough drying in an air current

be conveniently employed for calibration, as presented in Figures 10 and 12. The chromatograms from which the fluorescence scans were made are shown in Figures 11 and 13. The legend to Figure 13 contains a summary of a more detailed rapid method for preparing porphyrin methyl ester extract from urine for separation by TLC. When small samples are applied with self-filling micropipettes (Fig. 13), the porphyrin ester spots on the developed chromatogram have an area which falls completely within the field of the fluorescence TLCscanner. In this way the concentration can be determined by direct fluorescence scanning in comparison to a known standard mixture (Fig. 12). In contrast, the scanning chart shown in Figure 10 represents relative

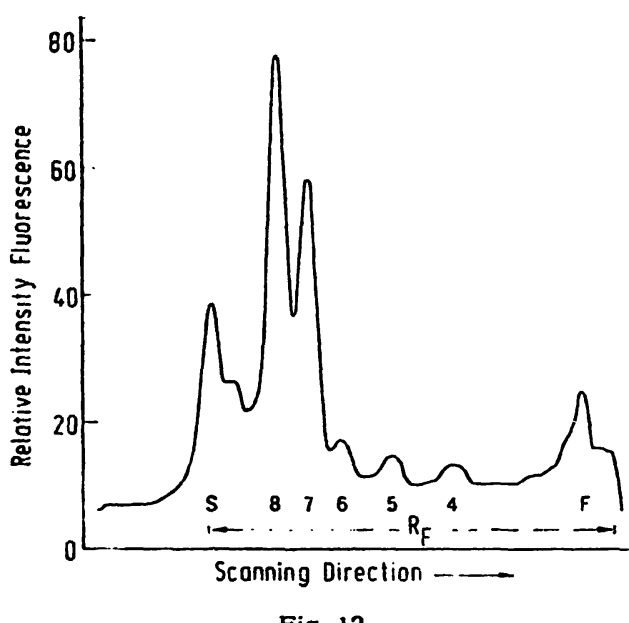

Fig. 12

Fluorescence scanning chart of entire spots of the porphyrin methy esters (P-ME) separated in position 3 on the chromatogram in Fig. 12 Width of the excitation slit 2.6 on the scanner scale. $S=$ start (first peak: non-porphyrin material; second peak: nonesterified uroporphyrin; see chroinatogram); $F=$ front peak of the solvent system; 8 to 4 : uro-, heptacarboxylic-, hexacarboxylic-, pentacarboxylic-, and copro-

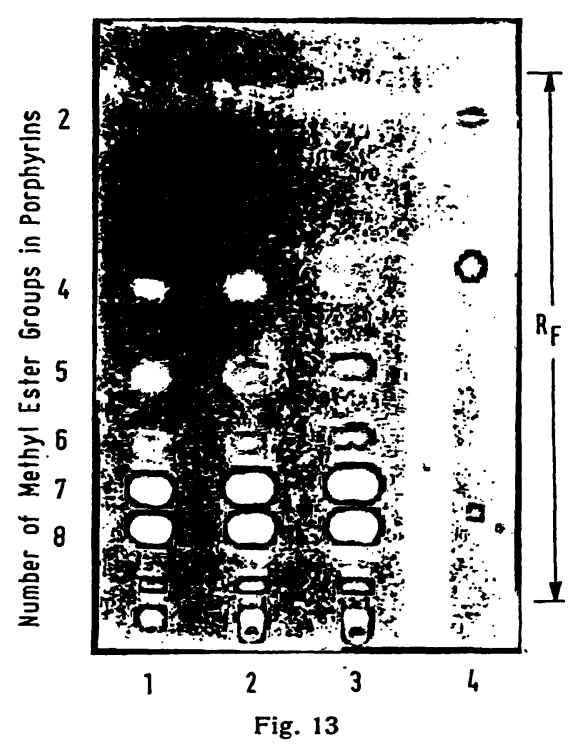

TLC separation of urinary porphyrins (human porphyria cutanea tarda) on a silica gel card (Riedel - de Haen) for the direct fluorometric measurement of the entire spots as shown in Fig. 12. The porphyrins from $10 \mathrm{ml}$ urine, containing $1.21 \mu \mathrm{g}$ of total porphyrins per $\mathrm{ml}$, were adsorbed on $0.5 \mathrm{~g}$ talc and centrifuged after adjustment of the urine sample to $\mathrm{pH} 4$ with glacial acetic acid. The talc, sedimented by short centrifugation and resuspended in methanol, was sedimented again and dried at $38^{\circ}$ (water bath) within 5 min under an $\mathrm{N}_{2}$-stream, then esterified with $3 \mathrm{ml}$ of methanol-sulphuric acid $(97+3, v+v)$ at $35^{\circ}$ for $30 \mathrm{~min}$. The porphyrin methyl esters were extracted as described in the text. After complete evaporation of the solvents the esters were dissolved in $200 \mu l$ chloroform. From this solution 40 (1), 50 (2), and 60 (3) $u l$ corresponding to $2,2.5$, and $3 \mathrm{ml}$ of urine, were applied on the card with $10 \mu l$ self-filling micro-pipettes (Camag). After the application of test abstances (4) the card was developed as described in the tion of test substances (4) the card was developed as described in the position 3 , is $9 \mathrm{~mm}$ wide and $6 \mathrm{~mm}$ high

Tab. 5

Comparison of the analysis of six thin-layer chromatograms, each containing porphyrins from $10 \mathrm{ml}$ of porphyric urine, by means of fluorescence scanning versus spectrophotometric measurement in chloroform solution

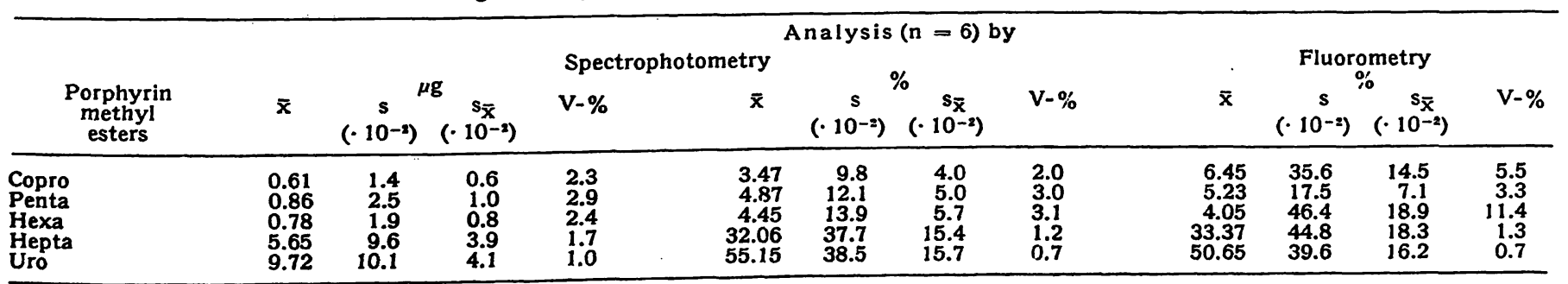

$\overline{\mathbf{x}}$ mean, $s$ standard deviation, $s_{\overline{\mathbf{x}}}$ standard deviation of the mean, $\mathrm{V}-\%$ variation coefficient 
Tab. 6

Separation of porphyrin methyl esters on various silica gel plates or sheets in the benzene-ethyl acetate-methanol system (85 $+13.5+1.5, v+v)$

\begin{tabular}{|c|c|c|c|c|c|c|c|c|c|c|}
\hline \multirow{2}{*}{$\begin{array}{c}\text { Ready-made silica gel } \\
\text { plates or cards } \\
\text { Type }\end{array}$} & \multirow{2}{*}{$\begin{array}{l}\text { Layer } \\
\text { thick- } \\
\text { ness } \\
\mathrm{mm}\end{array}$} & \multirow[b]{2}{*}{ PROTO } & \multicolumn{5}{|c|}{$R_{\mathrm{F}}$ values $(\times 100)$ of } & \multirow{2}{*}{$\begin{array}{l}\text { Time (min) } \\
\text { of develop- } \\
\text { ment for } \\
10 \mathrm{~cm} \\
\text { from start }\end{array}$} & \multirow{2}{*}{$\begin{array}{c}\text { Quality } \\
\text { of } \\
\text { separation }\end{array}$} & \multirow{2}{*}{$\begin{array}{l}\text { Porphyrin fluores- } \\
\text { cence on chromato- } \\
\text { grams under UV } \\
\text { light }(366 \mathrm{~nm})\end{array}$} \\
\hline & & & COPRO & PENTA & HEXA & HEPTA & URO & & & \\
\hline $\begin{array}{l}\text { Plates DSF-A } \\
\text { (Camag) }\end{array}$ & 0.2 & 88 & 62 & 50 & 38 & 29 & 20 & 36 & sharp & intense \\
\hline $\begin{array}{l}\text { Sheets MN-Polygram } \\
\text { Sil N-HR } \\
\text { (Macherey-Nagel \& Co.) }\end{array}$ & 0.2 & 91 & 60 & 43 & 30 & 20 & 11 & .31 & sharp & intense***) \\
\hline $\begin{array}{l}\text { Plates } F_{981} \\
\text { (Merch) }\end{array}$ & 0.25 & 93 & 78 & 63 & 52 & 42 & 30 & 39 & sHarp & very intense \\
\hline $\begin{array}{l}\text { Aluminium sheets } \\
\text { (Merck) }\end{array}$ & 0.25 & 92 & 80 & 67 & 56 & 47 & 32 & 35 & diffuse*) & ințense \\
\hline $\begin{array}{l}\text { Aluminium sheets } F_{284} \\
\text { (Merck) }\end{array}$ & 0.25 & 91 & 79 & 67 & 55 & 43 & 29 & 40 & diffuse*) & intense \\
\hline $\begin{array}{l}\text { DC cards SI } \\
\text { (Riedel-de Haën) }\end{array}$ & 0.2 & 86 & 65 & 50 & 38 & 28 & 18 & 52 & very sharp & very intense \\
\hline $\begin{array}{l}\text { Plates } \\
\text { (Schleicher \& Schüll) }\end{array}$ & 0.25 & 74 & 48 & 35 & 25 & 17 & 9 & 36 & very sharp & intense***) \\
\hline $\begin{array}{l}\text { Plastic sheets } \\
\text { (Schleicher \& Schüll) }\end{array}$ & 0.25 & 83 & 51 & 39 & 30 & 22 & 14 & 36 & very sharp & moderate***) \\
\hline $\begin{array}{l}\text { Cards Silufol UV254 } \\
\text { (Serva) }\end{array}$ & 0.1 & 97 & 87 & 77 & 67 & 56 & 40 & 43 & fair*) & moderate \\
\hline $\begin{array}{l}\text { Sheets without } \\
\text { fluorescence indicator } \\
\text { (Woelm) }\end{array}$ & 0.2 & 87 & 59 & 43 & 31 & 21 & 13 & 58 & very. sharp & very intense \\
\hline $\begin{array}{l}\text { Plates without } \\
\text { fluorescence indicator } \\
\text { (Woelm) }\end{array}$ & 0.3 & 62 & 37 & 25 & 17 & 11 & 6 & 29 & sharp**) & very intense \\
\hline
\end{tabular}

Chromatographic conditions: Camag-chamber (25250), $100 \mathrm{ml}$ solvent system, non-saturated atmosphere, temperature $22^{\circ}$. The starting line lies $2 \mathrm{~cm}$ from the lower edge

*) Separation is improved in chloroform (p. a., containing $1 \%$ ethanol)

**) Separation is improved in benzene-ethyl acetate-methanol $(85+13+2, v+v)$

***) Best detected on dry chromatograms

measurements of the porphyrin ester bands of a sample separated on the chromatocard in Fig. 11. The porphyrin zones of 6 chromatograms of this type, which had been made under identical conditions, were rapidly eluted with chloroform as described, and analyzed by spectrophotometry (6). The values for the percent composition of the porphyrin mixture, obtained both by spectrophotometry and fluorescence records, are given in Table 5. These data indicate relatively good agreement between the analyses in which the different methods were used.

However, it must be concluded on the basis of these studies that the fluorometric scanning of the porphyrins under the conditions described does not fully correspond to the spectrophotometric values for each porphyrin. On the basis of the quotients of spectrophotometric to fluorometric analysis of each porphyrin (Tab. 5) factors can be calculated, with the help of which the percentage of each porphyrin as determined fluorometrically can be converted into the same dimensions as the values obtained by spectrophotometry.

The fluorescence scanning method is highly sensitive (up to $10 \mathrm{ng}$ of porphyrin), and was employed for the registration of both proto- and coproporphyrin esters from gastric and duodenal secretions $(9,24)$, and of porphyrins from liver needle biopsy (25), separated on silica gel cards.

\section{Discussion}

The high quality of separation, reproducibility, rapidity, and simplicity of the differentiation of porphyrins as methyl esters in TLC on silica gel in combination with fluorometry and spectrophotometry fulfills the basic requirements for a usefúl microanalytic method. The application of this method in clinical-chemical diagnosis must, however, be facilitated by an even more extensive standardization of the individual steps.

Whereas the separation of the porphyrins according to the number of methyl ester groups is optimal, especially for analytical amounts, the problem of separating the isomers has not yet been solved to comparable degree. The products commercially available are not all equally suitable for the separation of porphyrin methyl esters by TLC on ready-made silica gel plates or cards as described in this paper. Several of the commercial TLC plates and cards were tested under standardized conditions (Tab. 6). A comparison of the chromatograms reveals differences in their separation properties, as well as in the intensity of fluorescence of the porphyrins. A satisfactory separation is probably possible on all readymade silica gel films tested, when the conditions under which the chromatography is carried out are suitably modified (chamber, solvent system, saturation of the atmosphere). The fluorescence of the porphyrins is most intense on certain silica gel aluminium sheets (Tab. 6).

On the basis of our tests the separation of porphyrins or their methyl esters in talc (26) offers neither theoretical nor practical advantages over that in silica gel. The separation of the porphyrins according to $R_{F}$ values, which increase with the number of carboxyl groups, does not appear advantageous in those cases in which uro- and heptacarboxylic porphyrins are the main components of a mixture. This is so in urine and liver tissue in Porphyria cutanea tarda (25), or in liver cell 
cultures (5), and certain bacterial suspensions (8) Fig. 2), to which $\delta$-aminolevulinic acid has been added to enhance the biosynthesis of porphyrins and heme. In analogy to the separation of lipids in $\operatorname{TLC}(13,27)$ we prefer to separate a mixture of the most polar substances in the lower $R_{F}$ range, using a lipophilic solvent system.

This work was supported by a generous grant from the Deutsche Forschungsgemeinschaft.

\section{References}

1. Demole, E., J.Chromatog. 1, 24 (1958). -2. Doss, M., in: Niederwieser, A., and G. Pataki (Editors), Progress in Thin-Layer Chromatography and Related Methods, Vol.3, Ann Arbor Science Publ. Inc., Ann Arbor, Michigan, in press. - 3. Doss, M., J. Chromatog. 30, 265 (1967). - 4. Doss, M., Dtsch. med. Wschr. 93, 2223 (1968). 5. Doss, M., this journal 7, 133 (1969). - 6. Doss, M., HoppeScyler's Z. physiol. Chem. 350, 499 (1969). - 7. Doss, M., and W. K.-PhILIPP, this journal 7, 148 (1969). - 8. Doss, M., Biochim. biophysica Acta (Amsterdam) 170, 461 (1968). - 9. Doss, M., and L. FilippinI, this journal 7, 306 (1969). - 10. Doss, M., Klin. Wschr. 47, 1280 (1969). - 11. Goldrick, B., and J. HirsCh, J. Lipid. Res. 4, 482 (1963). - 12. Doss, M., and H. Bürger, Hoppe-Seyler's Z. physiol. Chem. 348, 936 (1967). - 13. KLENK, E., and M. Doss, Hoppe-Seyler's Z. physiol. Chem. 342, 187 (1965). 14. Doss, M., and K. Oetre, Z. analyt. Chem. 243, 350 (1968). -
15. Doss, M., and U. Bode, J. Chromatog. 35, 248 (1968). 16. FALK, J.E., Porphyrins and Metalloporphyrins, Elsevier, Amsterdam (1964). - 17. Doss, M., and W. Mannhen, this journal 5, 260 (1967). - 18. Ulshörer, B., and M. Doss, J. Chromatog. 44, 407 (1969). - 19. Doss, M., Abstr. VII. Internat. Congress of Clin. Chem., p. 362. Geneve/Evian (1969), S. Karger, BaselNew York. - 20. Cardinal, R. A., I. Bossenmaier, Z. J. PeTRYKA, L. JoHnson, and C. WA'rson, J. Chromatog. 38, 100 (1968). 21. Doss, M., Klin. Wschr. 46, 731 (1968). - 22. Doss, M., B. UlshöfRR, and R. QuAst, J. Chromatog. 41, 386 (1969). 23. JAnCHEN, D., and G. PATAKI, J. Chromatog. 33, 391 (1968). 24. Doss, M., and L. Filippini, Dtsch. med. Wschr. 94, 2392 (1969). - 25. Doss, M., Dtsch. med. Wschr. 95, 959 (1970). 26. With, T. K., J. Chromatog. 42, 389 (1969). - 27. OEtre, K., and M. Doss, J. Chromatog. 32, 439 (1968).

Priv.-Doz. Dr. Manfred Doss D-355 Marburg/Lahn, B.R.D. Pilgrimstein 2 